\author{
ANNA NACHER \\ Jagiellonian University in Cracow, Poland
}

FILIP JANKOWSKI

Faculty of Management and Social Communication Jagiellonian University in Cracow, Poland
Images

vol. XXIX/no. 38

Poznań 2021

ISSN 1731-450X

\title{
Re-writing histories of colonization in video games: the case of Elizabeth LaPensée
}

\begin{abstract}
Nacher Anna, Jankowski Filip, Re-writing histories of colonization in video games: the case of Elizabeth LaPensée. "Images” vol. XXIX, no. 38. Poznań 2021. Adam Mickiewicz University Press. Pp. 123-141. ISSN 1731-450X. DOI 10.14746/i.2021.38.08.

The article is aimed at presentation of the case study in video games creation by Indigenous auteur and designer, Elizabeth LaPensée, which at the same time demonstrates how video games can both mediatize the process of re-writing history and decolonize popular imagination. The analysis of LaPensée's three games: Invaders, Thunderbird Strikes, and When the Rivers Were Trails to some extent follows her own strategies of self-identification as Anishinabee (Ojibwe). Drawing upon reconfiguration of the auteur theory and the framework of ludostylistics by Astrid Ensslin, we also strive to demonstrate how the notion of a singular author is in fact grounded in collective and collaborative qualities of indigenous digital culture, including digital game design.
\end{abstract}

KEYwORDs: Elizabeth LaPensée, indigenous digital culture, indigenous video games, decolonization, Ojibwe

In the last decade of the 21st century, we can observe an increase in the number of digital games referring to the experience of ethnic minorities, including Indigenous people, increasingly referred to as BIPOC: Black, Indigenous, Persons of Color. The tendency is not without notable precedents; one of them is especially worth acknowledging as the work of African-Caribbean designer Muriel Tramis in the 1980s, still being discovered by academic discourse, $[1]$ seems to bear particular significance in this perspective.

Before we further proceed with our analysis, a clarification on certain terminological instability seems necessary. We choose to favor semantic fluidity over conforming to the rules of academic discourse, which in case of the topic discussed here may come not only as superficial, but also as a strategy of colonial erasure. Different referents for the

[1] Cf. J. Bazile, L'Histoire à traverser. Regards vidéoludiques sur l'histoire de la Martinique dans Mewilo et Freedom de Muriel Tramis, [in:] Chemins de Traverse en fiction. Colloque interdisciplinaire de jeunes chercheureuses, École normale supérieure (ENS), Paris 2017, pp. 177-190; A.Y. Chang, Une Vie Bien Jouée/A Life Well Played: The cultural legacy of game designer Muriel Tramis, "Feminist Media Histories" 2020, no. 1, pp. 147-162, DOI: 10.1525/ fmh.2020.6.1.147; F. Jankowski, "Méwilo" $i$ „Freedom” Muriel Tramis jako pierwsze gry postkolonialne" [in:] Ksenologie, eds. K. Olkusz, K.M. Maj, Kraków 2018, pp. $473-485$. 
indigenous inhabitants of the American continent are used throughout the article, which may come across as a lack of consistency, yet it is a conscious decision. Favoring such a controversial semantic strategy, we want to emphasize that even terminology denoting the Indigenous nations of the continent is becoming the subject of decolonization. In doing so, we follow the explanation provided by R. Dunbar-Ortiz, who interchangeably uses "Indigenous", "Indian", and "Native", and prefers their nations' names in their own languages. Hence, we also refer to Anishinaabe (and bracket Ojibwe). The specific terminological decisions follow different naming patterns used by artists, researchers and critics whose work we analyze or quote. It is also worth acknowledging that Dunbar-Ortiz advises against using popular and still broadly used terms, such as "tribe".[2]

In our article, we want to demonstrate that the way the descendants of the American First Nations have also recently been more vocal in the gaming industry and digital culture at large, which can be seen as inscribed within the larger processes of decolonization, based on "reclaiming the territory", on par with other decolonizing strategies and gestures. Therefore, we want to start with a brief outline of the initiatives which have long served as a fertile ground for indigenous digital creativity. In this way, we want to emphasize the crucial significance of organizations, programs and initiatives undertaken and led by Indigeous artists, scholars, activists and IT specialists. In a domain based on collaborative work, the ability to foster and maintain networks of cooperation across various levels of skillsets and engagements needs to be acknowledged and praised. Such an approach allows also for situating the original, individual work in the broader web of relations and provides the ground for seeing the Indigenous creation as paradigmatic rather than exceptional or exotic. There are a few prominent examples coming from the broadly-defined field of gaming, including the long-discussed but underappreciated Kisima Ingitchuna (Upper One Games, 2014), where the playable story of young Alaskan girl struggling and coexisting with natural forces intertwines with commentaries by Native Americans living in Alaska. Other examples worth mentioning have been devised by Canadian Mohawk multimedia and digital artist and independent game designer, Skawennati (Skawennati Tricia Fragnito), often working in collaboration with her partner, Jason Edward Lewis, a professor at the Department of Design and Computation Arts at Concordia University in Montreal. She is best known for her machinima artwork, Time Traveler ${ }^{\mathrm{TM}}$ (2009), where the seminal events from the tragic history of American Indians constitute the significant point of reference (including the massacres and persecution of Indigenous communities after the U.S. Dakota War in 1862 and 1863). The series followed Skawennati's first serious creative encounter with digital tools,

[2] R. Dunbar-Ortiz, An Indigenous Peoples' History of the United States, Boston 2014. 
CyberPowWow, an online community established in 1997 which functioned until 2001 and eventually morphed into $\mathrm{AbTeC}$, an acronym that stands for Aboriginal Territories in Cyberspace. It offered digital space both to present Skawennati's machinima projects and her first ventures into Second Life and develop other First People's storytelling projects. The First People Postsecondary Storytelling Exchange is an example of an initiative aimed at strengthening learning and teaching through various form of storytelling in the region surrounding Montreal (talking circles, filmmaking, digital media). Eventually, AbTec moved entirely to Second Life and rebranded as AbTeC Island, complete with a gallery, where digital works by contemporary Canadian Indigenous artists, such as Rebecca Belmore and Nadia Myre have been on display virtually. The creators defined $\mathrm{AbTeC}$ as "Aboriginally determined research-creation network whose goal is to ensure Indigenous presence in the web pages, online environments, video games, and virtual worlds that comprise cyberspace." [3]

Skawennati's and the team's insistence on literally gaining ground in cyberspace may be related to the fact that questions pertaining to land ownership feature prominently at the very heart of American colonialism. One needs to remember that disputes, clashes and violent conflicts about land (as well as various forms of land grabbing) constitute the very core of settler colonialism and its mechanisms of oppression (or, more precisely, "genocidal policy"[4]). Patrick Wolfe emphasizes in his seminal article that "[1] and is life - or, at least, land is necessary for life. Thus contests for land can be - indeed, often are contests for life." [5] The inevitable ambiguities related to thinking in terms of physical land ownership in virtual environments are adequately illustrated by an incident that took place when the team worked on Second Life, setting the stage for their Machinima project. At some point, the artists discovered that the space and tools assigned to them by Linden Lab had been appropriated or, more precisely, squatted, by a group called "Prim Pirates". The clash immediately turned into a play of ironies, according to Elizabeth LaPensée and Jason Edward Lewis (themselves digital artists and scholars), who noticed that "on top of the existing irony of Indians buying virtual land and then colonizing it, there was now an additional irony of having to enclose the land to protect it from counter-colonization." [6]

It does not come as a surprise, then, that Skawennati strongly focuses on carving out virtual niches for Indigenous creative endeavors in an environment increasingly dependent on commercial social media

[3] Home website, <https://abtec.org/\#about>, accessed: 29.12.2020.

[4] R. Dunbar-Ortiz, op.cit., p. 6.

[5] P. Wolfe, Settler colonialism and the elimination of the native, "Journal of Genocide Research" 2006, vol. 8, no. 4, pp. 387-409, DOI: $10.1080 / 14623520601056240$.
[6] E. LaPensée, J.E. Lewis, Call it a vision quest: $M a-$ chinima in a first nations context, [in:] Understanding Machinima: Essays on Filmmaking in Virtual Worlds, ed. J. Ng, New York - London 2013, pp. 187-206. 
platforms. To this end, AbTeC, co-directed by Jason Edward Lewis, serves as an umbrella platform, hosting a series of initiatives aimed at expanding Indigenous presence in cyberspace, including in game development. Among the whole plethora of projects hosted on the platform, Initiative for Indigenous Futures stands out: it offers a series of workshops in game development for Indigenous youth (SKINS Workshop on Aboriginal Storytelling and Indigenous Game Design) and an experiment in developing a Native American programming language based on translation of C\# into Hawaiian 'ōlelo Hawai' I, co-authored by Lewis and the team (Kari Noe, Nathan Nahina, Kauwila Mahi, and Noe Arista).[7]

Therefore, pursuing the possible ways of decolonizing digital culture, in this article we will provide insight into the specific aesthetic and rhetoric strategies of game design demonstrating complexity of the situation of indigenous people in North America. At the same time, we are well aware that "decolonization is not a metaphor," [8] that it "should be unsettling" and that "[t]he easy absorption, adoption, and transposing of decolonization is yet another form of settler appropriation." [9] Hence, we are not seeking any "moves to innocence" [10] (meant to primarily alleviate the guilt of the white/settler privilege), but humbly propose starting with a very simple and obvious first step: recognition and acknowledgement of the contribution of a game designer identifying as Indigenous/American Indian/First Nations, and placing it within the framework of the mainstream game analysis. The

[7] Programming in Indigenous languages is increasingly a hot topic of both scholarly debates and practical experiments in pursuits to decolonize the digital culture at large. Among the most prominent examples of the latter are the programming languages based on Yoruba (Yorlang, developed by a Nigerian programmer, Karounwi Anu) or Cree (Cree\#, developed by Jon M.R. Corbett, of a Metis background). The scholarly literature on the subject includes the following seminal studies: O. Laiti, Ethnoprogramming: An Indigenous Approach to Computer Programming: A Case Study in Ohcejohka Area Comprehensive Schools, unpublished Master thesis, University of Lapland, 2016, <https://lauda.ulapland.fi/handle/10024/62624>, accessed: 2.01.2021; J.E. Lewis, N. Arista, A. Pechawis, S. Kite, Making Kin with the machines, "Journal of Design and Science" 2018, July 16, DOI: 10.21428/ bfafd97b; M.C. Marino, Critical Code Studies: Initial Methods, The Cambridge, MA, 2020. While working on this topic, I (AN) also benefited from the participation in Critical Code Studies Working Group 2020 held in January and February 2020, Cf: CCS Working Group 2020, Week 2: Indigenous Programming (by J. Corbett, O. Laiti, J.E. Lewis, D. Temkin, available (upon login) at: <http://wg2o.criticalcodestudies. com/index.php? $\mathrm{p}=/$ discussion/70/week-2-indigenous-programming-main-thread\#latest $>$, accessed: 28.12.2O2O.

[8] E. Tuck, K. Wayne Yang, Decolonization is not a metaphor, "Decolonization: Indigeneity, Education \& Society" 2012, vol. 1, <https://jps.library.utoronto. ca/index.php/des/article/view/18630>, accessed: 3.01.2021, p. 3.

[9] Ibidem, p. 4.

[10] The notion of the "moves to innocence" has been coined by Janet Mawhinney who defined it as "strategies to remove involvement in and culpability for systems of domination", drawing from the concept of "the race to innocence" proposed by Mary Louise Fellows and Sherene Razack (Cf. J.L. Mawhinney, Giving Up the Ghost: Disrupting the (Re)Production of White Privilege in Anti-Racist Pedagogy and Organizational Change, unpublished Master thesis, University of Toronto, Toronto 1998, <https://tspace.library.utoronto.ca/ handle/1807/12096>, accessed: 3.01.2021; M. Fellows, S. Razack, The race to innocence: confronting hierarchical relations among women, "Journal of Gender, Race \& Justice", 1998, vol. 1, January 1, pp. 335-352, <https:// scholarship.law.umn.edu/faculty_articles/274>, accessed: 3.01.2021; E. Tuck, K. Wayne Yang, op.cit. 
focus here is on the work by Elizabeth LaPensée, already mentioned above, a bilingual (fluent in French and English) female game designer and scholar, claiming various backgrounds (Anishinaabe, Métis and Irish). She received higher education in Canada, but she currently teaches in the United States (specifically at Michigan State University near the U.S.-Canadian border), and her creative output reveals many complexities concerning national and ethnic identities. Just as in the case of Muriel Tramis mentioned at the beginning, LaPensée's games are rooted in local heritage and are critical of the historical past (including settler colonialism[11]), as we intend to demonstrate.

In this article, we aim to show how video games mediatize the process of re-writing history. By saying "re-writing", we refer to the notion coined by Diane Brydon. Brydon defines "re-writing" as the process perpetuated by post-colonial writers who inherit the canonical texts from the imperial tradition "in order to re-define themselves according to their own understanding of tradition." [12] This term can find its use not only in literature or films, but also in video games. Examining LaPensée's selected titles, we intend to show how game developers can re-write dominant canonical texts of digital entertainment, both through re-designed gameplay and content.

The choice of LaPensée's ouevre as the objects of research is justified, insomuch that it is foregrounded in the solid theoretical framework. LaPensée has regularly written about her educational games in scholarly publications, justifying her creative process and ideological message by standing by her titles.[13] While extensive studies have been undertaken which depict the profound connections between video games and U.S. or British imperialism,[14] we can still observe a research loophole in indicating (de)constructive counter-proposals which would challenge such imperialism as such, not to mention its more specific and particular form constituted by settler colonialism. Among the exceptions, one can find Vit Šisler's study of Arabian video games resistant to the dominant Western ideologies[15] or, as cited

[11] The good starting point to further explore already extensive and robust discussion of the term is offered in: P. Wolfe, Settler colonialism..., Even provisionary acquaintance with the discussion provides the ground for better understanding how unsettling the decolonization can be, as according to Roxanne Dunbar-Ortiz, "The history of the United States is a history of settler colonialism - the founding of a state based on ideology of white supremacy, the widespread practice of African slavery, and a policy of genocide and land theft." (R. Dunbar-Ortiz, op.cit., p. 2).

[12] D. Brydon, Re-writing The Tempest, "World Literature Written in English" 1984, vol. 23, no. 1, p. $75-88$, DOI: $10.1080 / 17449858408588811$.

[13] See E. LaPensée, Survivance: An Indigenous
Social Impact Game, Burnaby 2014, <http://web. archive.org/web/20200308205719/https://summit.sfu. ca/item/13984>, accessed: 3.01.2021; eadem, Thunderbird strike, [in:] Learning, Education \& Games, vol. 3: 100 Games to Use in the Classroom \& Beyond, ed. K. Schrier, Pittsburgh 2019, pp. 447-453; E. LaPensée, N. Emmons, Indigenizing education with the game When Rivers Were Trails, "Amerikastudien" 2019, vol. 64, no. 1, pp. 75-93, DOI: 10.33675/ AMST/2019/1/8.

[14] N. Dyer-Witheford, G. De Peuter, Games of Empire: Global capitalism and video games, Minneapolis 2009; S. Mukherjee, Videogames and Postcolonialism, New York 2017.

[15] V. Šisler, Digital Arabs: representation in video games, "European Journal of Cultural 
before, LaPensée's articles about her own games. Following her own strategies of ethnic and national identifications, we will refer to the context of Canadian Anishinaabe (Ojibwe), although the presence of this Native nation transcends the current borders of the nation states of Northern America.[16]

Here it is necessary to explain why we refer to selected games in the context of a specific author. While there is no denying that critical examination of literary, cinematic, or ludic texts in terms of the auteur theory weakened after the post-structuralist turn,[17] we follow the traditional attitude of David Bordwell. Bordwell,[18] in his cognitive model of film analysis, asserts that the personification schemata in critical interpretations of texts is profoundly rooted in the long-lasting Western tradition, even though there the critic can produce symptomatic meanings never explicated by the creator themself. There are also creators who desire to be interpreted and, drawing from earlier theoretical art concepts, encourage critics to invent new concepts. This practice can also concern the creators of video games; in the last decade, academic writing has drawn closer attention to particular artists, rationalizing their work via personification[19]. Dominika Staszenko in particular, relying on Espen Aarseth's theory, underlines that auteur theory can be defended within the field of video games. According to Staszenko, one can define an auteur if he or she conceived at least two games, is recognized as an individual, and his or her titles distinguish themselves among the games of the same ludic genre.[20]

In this article, therefore, we decided to grasp the auteur politics of decolonizing "re-writing" that LaPensée used in the games she conceived and/or co-created with other artists or writers. Before explaining the methods used to analyze her selected titles, we need to sketch the historical context which contributed to her latest work: the fate of the Anishinaabe nation to which she belongs, and the aggressive European colonialism which oppressed them.

Historical context

As is well known, the descendants of French European settlers in Canada (particularly in Quebec) showed strong aspirations of claiming

Studies" 2008, vol. 11, no. 2, pp. 203-220, DOI: $10.1177 / 1367549407088333$.

[16] Even the terminology denoting the Indigenous nations of the continent is becoming the subject of decolonization. We follow the explanation provided by R. Dunbar-Ortiz, who interchangeably uses "Indigenous", "Indian", and "Native" and prefers their nations' names in their own languages. Hence, we refer to Anishinaabe (and bracketing Ojibwe). Dunbar-Ortiz also advises against using the term "tribe". Cf. A. Dunbar-Ortiz, op.cit.

[17] Cf. R. Barthes, The death of the author, [in:] idem, Image, Music, Text, trans. S. Heath, London
1977, pp. 3-8; M. Foucault, Authorship: what is an author?t, "Screen" 1979, vol. 20, no. 1, pp. 13-34, DOI: 10.1093/screen/20.1.13.

[18] D. Bordwell, Making Meaning: Inference and Rhetoric in the Interpretation of Cinema, Cambridge London 1989.

[19] D. Staszenko, Lollipop Chainsaw Goichiego Sudy $i$ problem autorstwa $w$ medium gier wideo, „Homo Ludens” 2015, vol. 7, no. 2, pp. 153-162; A. Strużyna, Artystyczne gry Anny Anthropy, "Homo Ludens" 2014, vol. 6, no. 1, pp. 187-198.

[20] D. Staszenko, op.cit., pp. 154-155. 
independence, living the myth of New France. For them, beginning in 1608 (the foundation of Fort Québec) but ending in 1763 (the French defeat in the Seven Years War against the United Kingdom), the century-and-a-half colonization of Canada has been treated with nostalgia. However, the Canadian Anishinaabe (Ojibwe) peoples would not say the same about the myth of New France. While between the 17th and 18th centuries there were about 8,000-10,000 Anishinaabe in the colonized lands, during the decline of the French colonies, only about 3,000 Anishinaabe remained, due to sensitivity to diseases brought from Europe, as well as wars and the destruction of hunting grounds by settlers. [21]

However, Anishinaabe's contacts with French settlers were not restricted to physical violence; some contact involved independent traders called coureurs $d u$ bois, who raped - and then married - women of the First Nations, thus giving birth to the population of Canadian Métis. [22] Therefore, the myth of New France was built upon physical and sexual repressions directed against Natives, but also on profound contact between the French and Anishinaabe cultures. This process, called métissage, problematized racial or cultural divisions, oscillated between homogenity and heterogeneity: "The métissage is not fusion, cohesion, osmosis, but confrontation and dialogue." [23] Even though as several theorists point out[24] - the term métissage has been misused as referring to any forms of cultural blending, we still think that it can indicate the complicated past of the Great Lakes region.

When the lands of New France were conquered by the United Kingdom in 1763 and parts of its territory became incorporated into the United States after the American Revolution 20 years later, the situation of Anishinaabe continued to worsen. The British-operated government in Canada tried to educate and assimilate Native populations, [25] while at the same time harshly weakening their economy by transferring their land to the Crown[26]; nevertheless, British-Canadian policy towards Anishinaabe has been labeled as genocide, due to the oppressive institutions of residential schools[27], with their "underfunding, the woeful

[21] M. Kijewska-Trembecka, Québec i Québécois: ideologie dążeń niepodległościowych, Kraków 2007, p. 37.

[22] M. Trudel, The Beginnings of New France, 1524-1663, Toronto 1973, pp. 154-155.

[23] F. Laplantine, A. Nouss, Le métissage: un exposé pour comprendre, un essai pour réfléchir, Paris 1997, p. 5, <http://classes.bnf.fr/actes/8/laplantine.pdf>, accessed: 2.01.2021.

[24] J.-X. Ridon, Littérature-Monde, or redefining exotic literature?, [in:] Transnational French Studies: Postcolonialism and Littérature-Monde, eds. A.G. Hargreaves, C. Forsdick, D. Murphy, Liverpool 2010, p. 204; R. Toumson, Mythologie du métissage, [in:] Francophonie et identités culturelles, ed. C. Albert, Paris 1999, pp. 241-246.
[25] J.R. Miller, Skyscrapers Hide the Heavens: A History of Indian - White relations in Canada, Toronto Buffalo 200o, pp. 130-136.

[26] Ibidem, pp. 216-22o.

[27] B. Elias et al., Trauma and suicide behaviour histories among a Canadian indigenous population: An empirical exploration of the potential role of Canada's residential school system, "Social Science \& Medicine" 2012, vol. 74, no. 10, pp. 1560-1569, DOI: 10.1016/j.socscimed.2012.01.026; Ch. Powell, J. Peristerakis, Genocide in Canada: A relational view, [in:] Colonial Genocide in Indigenous North America, eds. A.J. Woolford, J. Benvenuto, A.L. Hinton - Durham 2014, pp. 70-92. 
condition of the buildings, and the infection and death of children from tuberculosis." [28] Meanwhile, U.S. policy towards Anishinaabe - and other indigenous populations - relied on direct extermination; apart from acquiring indigenous lands, the U.S. government forced numerous indigenous people on the East to move towards the West of the Mississippi River between 1830 and 1840. Having acquired their lands, U.S. government and European-American settlers continued the policy of massacre and resettlement until the 189os.[29] As Jean-Louis Vullierme argues in his book Miroir de l'Occident, such politics on the part of the United States laid the foundations for European racist ideology:

Racism was not an accident, a temporary defect that could be overcome by the abolition of slavery, but a structural solution to a structural problem. It was certainly not unique to the United States, and in Europe, before and after Nazism, populism, whether left or right, was often racially motivated. America, however, had a particular predisposition for it, being the most segmented of all the developed countries, even though its national political myth is based exclusively on the idea of stratification.[30]

According to Vullierme, the United States inspired such political leaders as Adolf Hitler to enact similar politics of exploitation against countries in the Eastern Europe. Racism against underprivileged groups such as Native Americans, African-Americans, Asian immigrants, "white trash", and so on was directly supported by the popular culture in the United States: "Western cinema, of which Hitler was a great fan, portrayed Negroes as «good» and devoted, and Indians [...] as «bad,» except when they were weak recruits as scouts in the cavalry of good men." [31] The disruptive influence of Western literature, films, and video games was criticized in LaPensée's games, as we intend to demonstrate via the examples of her works.

\section{Methods of analysis}

To indicate how LaPensée's works re-write the classical conquer-based video games, we chose three positions from her oeuvre, differing in terms of the gameplay. Invaders, [32] a shooting-based video game, is a variation on Space Invaders. [33] Thunderbird Strike[34] relies on the tropes of side-scrolling video games. Finally, When Rivers Were Trails,[35] a narrative game, subverts many tropes from The Oregon Trail. [36]

These three games were analyzed using Astrid Ensslin's theoretical framework. Functional ludostylistics, as Ensslin names it, is composed of four components: ludology, ludonarratology, ludosemi-

[28] J.S. Milloy, M.J. McCallum, A National Crime: The Canadian government and the residential school system, Winnipeg, Manitoba, 2017, p. 105.

[29] D.E. Stannard, American Holocaust: The conquest of the new world, New York 1993, pp. 121-128, 130-134. [30] J.-L. Vullierme, Miroir de l'Occident: Le nazisme et la civilisation occidentale, Paris 2014, para. 9.132. [31] Ibidem, para. 9.114.
[32] E. LaPensée, Invaders, Linux, Survivance, 2015.

[33] T. Nishikado, Space Invaders, Arcade, Taito, 1978.

[34] E. LaPensée, Thunderbird Strike...

[35] Eadem, When Rivers Were Trails, Linux, Indian

Land Tenure Foundation, Michigan State University's GEL Lab, 2019.

[36] D. Rawitsch, B. Heinemann, P. Dillenberger, The Oregon Trail, Multiple platforms, MECC, 1971. 
otics and mediality (which we later emphasize with codes in brackets). Ludology, as Ensslin explains, includes ludic mechanics such as rules [L1], gameplay [L2], game architecture [L3], victory and termination conditions [L4], risks and challenges [L5], feedback [L6], agency [L7], game genres [L8] and types of play [L9]. Ludonarratology analyzes such elements as in-game narrative [LN1], game-story relationship [LN2], and external narrativity [LN3]. Ludosemiotics examines such game aspects as interface design [LS1], verbal language [LS2], text and discourse [LS 3 , procedural rhetoric [LS4], and multimodality [LS5]. Finally, mediality involves such elements as platform [M1], hardware [M2], software [M3], ergodicity (nontrivial interactivity) [M4], and textuality $\left[\mathrm{M}_{5}\right]$, "that is, the ways in which the text at hand interrelates to other texts and media." [37]

Not all of the aforementioned aspects could be indicated during further analysis, but citing them hopefully makes the subsequent readings more transparent. Although game studies forged some other theoretical frameworks concerning video game analysis, they are either too general or vague[38], or too formalist in their attitude to game analysis. [39] Moreover, Ensslin's proposal successfully reconciles various approaches to game studies, standing beyond the ludology vs. narratology vs. proceduralism debate.[40]

The three selected games were played at least twice on selected gaming platforms. We tested Invaders on the Chrome web browser, Thunderbird Strike on the Android mobile operating system, and When Rivers Were Trails on a personal computer with Linux Mint OS. All of these games are also available on the Windows operating system, though none of us used it during analysis.

Invaders is a two-dimensional shooting game programmed for Invaders browsers and mobile platforms (Android and iOS) [M1, M2, LS1, L8], designed with the Unity engine $\left[\mathrm{M}_{3}\right]$. From the beginning, it constitutes the polemics with the well-known arcade game Space Invaders [M5].

[37] A. Ensslin, Literary Gaming, Cambridge - London 2014, pp. 52-53.

[38] E. Aarseth, Playing research: methodological approaches to game analysis, [in:] Game Approaches / Spil-Veje. Papers from Spilforskning.Dk Conference, ed. B.K. Walther, Aalborg 2004, pp. 28-29, <http:// www.bendevane.com/VTA2012/herrstubbz/wp-content/uploads/2012/o1/o2.GameApproaches2.pdf>, accessed: 2.01.2021; L. Konzack, Computer game criticism: A method for computer game analysis, [in:] Video Games and Gaming Culture, ed. M.J.P. Wolf, New York - London 2016.

[39] C. Fernández-Vara, Introduction to Game Analysis, New York - London 2015; cf. T. Majkowski, Języki gropowieści. Studia o różnojęzyczności gier cyfrowych, Kraków 2019.
[40] I. Bogost, Persuasive Games: The expressive power of video games, Cambridge 2007; M. Eskelinen, The gaming situation, "Game Studies" 2001, vol. 1, no. 1, <http://www.gamestudies.org/o101/eskelinen/>, accessed: 1.01.2021; H. Jenkins, Game design as narrative, "Computer" 2004, vol. 44, no. 53, pp. 118-130; J. Juul, Games telling stories? A brief note on games and narratives, "Game Studies" 2001, vol. 1, no. 1, <http:// www.gamestudies.org/o101/juul-gts/>, accessed: 1.01.2021; S. Mukherjee, Video Games and Storytelling: Reading Games and Playing Books, London 2015; Miguel Sicart, Against procedurality, "Game Studies" 2011, vol. 11, no. 3, <http://gamestudies.org/1103/articles/sicart>, accessed: 1.01.2021. 
Tomohiro Nishikado's Japanese shooting game was described as reflecting "xenophobic invasion of the Other," [41] whether the Other would impersonate the American cultural invasion of Japan or conversely, as "a defense of American individualism against the power and efficacy of Japanese collectivism and corporate culture." [42] Mia Consalvo cites Nishikado's confession that both Imperial invaders from Star Wars and sea creatures from the local culture served as an inspiration for the ludic attackers.[43] However, this ambiguity evaporates in LaPensée's re-interpretation of Space Invaders.

The gameplay of Invaders, just like that of the game's predecessor, relies on defense against aliens. These crawl towards the bottom of the screen and shoot at the player with laser guns [L1, L5]. However, whereas in Nishikado's game the player could steer a spaceship equipped with a laser gun, LaPensée's playable figures are Natives carrying bows and arrows [ $\left.\mathrm{L}_{2}, \mathrm{LN}_{1}\right]$. Thus, the level of difficulty increases rapidly [L3]. After dealing with the fairly easy first wave of invaders, the player quickly encounters a deluge of aliens making use of laser projectiles and fire missiles flooding the screen. Avoiding them is very difficult, and the only bonuses the player can collect allow for mere temporary acceleration of their firing rate [L7]. The player realizes that the fight is uneven. Moreover, every loss of life points results in an indigenous archer leaving the screen; if the player loses all their archers, the game is lost [L4].

As the player can easily recognize, LaPensée's Invaders clearly depict the culture shock which the indigenous people experienced while encountering the better-equipped European settlers [LS $3, \mathrm{LS}_{4}$ ]. Although the gameplay itself is close to Space Invaders, the semiotic shift of the playable figure (a spaceship replaced with indigenous archers) significantly changes the meaning of LaPensée's game. Thus, the player becomes more aware of how the Europeans' outrageous technological advantage decimated the indigenous people.

Thunderbird Strike

However, it was another of LaPensée's games, funded by the Minnesota's Legacy Fund, which sparked much controversy. As she described it, "Oil lobbyists targeted Thunderbird Strike, ranging from a media smear campaign calling for completely shutting down the game to a failed attempt to revoke funding from the arts grant to then attempting to create a new bill to invoke a civil penalty on any art which is deemed by that governing body to promote domestic terrorism." [44]

[41] E. Zimmerman, Eric Zimmerman's Response, "Electronic Book Review" (blog), 2004, August 1, $<$ https://electronicbookreview.com/essay/eric-zimmermans-response/>, accessed 1.01.2021.

[42] L. Grace, Space Invaders at 40: What the game says about the 1970 - and Today "The Independent" 2018, June 21, <https://www.independent.co.uk/ life-style/gadgets-and-tech/space-invaders-game1970s-a8405886.html>, accessed: 1.01.2021.

[43] M. Consalvo, Console video games and global corporations, "New Media \& Society" 2006, no. 1, pp. 117-133, DOI: 10.1177/1461444806059921.

[44] E. LaPensée, Thunderbird Strike..., p. 449. 
That is not imagination on the part of the artist. A certain Republican senator from Minnesota, David Osmek, in a populist tone accused the game's author of creating "an eco-terrorist version of Angry Birds": "When the Legacy Amendment to our constitution was approved, no voter could have imagined that our taxpayer dollars would be used to fund video games that blow up pipelines." [45]

Regardless of the inaccurate game genre intimation, Osmek's concerns were shrewd. As LaPensée said in an interview for the Canadian Broadcasting Channel, she had developed Thunderbird Strike to criticize the oil industry's investment on Turtle Island, where she had lived. The oil pipeline, which would intersect the Island, caused worry for the Island's inhabitants, as it could be potentially devastating, both for the environment and the human population [LS3]: "I was very concerned about and listening to the stories of my community members and storytellers and elders regarding there becoming a time when there will be a snake that threatens to swallow the land and the waters whole. So Thunderbird Strike really does reflect the stories of community members." [46]

Thunderbird Strike, just like Invaders, was also designed with Unity and released on mobile platforms and the Windows operating system $\left[\mathrm{M}_{1}, \mathrm{M}_{2}, \mathrm{M}_{3}\right]$. Thunderbird Strike does contain several video interludes, though [LS5]. The first video imaginatively demonstrates how the Lake Winnipeg in Alberta and the Great Lakes are connected with oil pipelines, which transfer into the aforementioned snake. Then, the player observes an animation depicting a row of trucks, and then several animal corpses turn into living bodies. Then, a mythological creature, which the North American indigenous people call the Thunderbird, appears [LN1].

Steering Thunderbird, the player moves in a two-dimensional side-scrolling environment [L2, LS1]. During the first two levels, the gameplay is much simpler than in Invaders. The player needs only to fly up and be charged by lightning, and then dive down and make use of the gathered energy [L1]. The player can use the energy in two ways: by destroying trucks, refineries and oil wells, and/or by reviving the corpses of animals and indigenous people who lost their lives as a result of the investments $\left[\mathrm{L}_{7}\right]$. However, the game proceeds differently on the third level, when the player's objective is to defeat the snake personifying the pipeline. On this level, Thunderbird Strike invokes the convention of side-scrolling shooting games, with "bosses" (big enemies) confronting the player at the end [L8]. To win the battle with

[45] Minnesota Senate Republicans, "Sen. David Osmek: MN Taxpayers Should Not Be Funding Angry Birds for Eco-Terrorists," Minnesota Senate Republicans (blog), October 26, 2017, <https://www. mnsenaterepublicans.com/sen-david-osmek-mntaxpayers-not-funding-angry-birds-eco-terrorists/>, accessed: 1.01.2021.
[46] CBC Radio, Thunderbird Strike: Controversial video game takes aim at oil industry, "CBC", 2017, November 3, https://www.cbc.ca/radio/unreserved/ from-video-games-to-ya-novels-how-indigenousart-is-evolving-1.4384041/thunderbird-strike-controversial-video-game-takes-aim-at-oil-industry-1.4384559>, accessed: 1.01.2021. 
the snake, one must attack its weakest points, marked with oil gushing from the "boss" [L5].

Having defeated the snake, the player observes the final video, which shows the possible ways of preventing the possible catastrophe in real life. These are, for example, renaturing the populations of endangered species and replacing oil wells with wind farms [LS4, L4]. Of course, Thunderbird Strike in its emerging message may be "eco-terrorist", as Osmek insists. However, the about 3,00o US dollars which LaPensée earned for the game[47] is nothing when we consider that, according to official statistics, "Canadian oil and gas extraction companies reported $\$ 573.9$ billion in total assets in 2017." [48] The game, which features a minimal number of words [LS2], communicates its message clearly: oil companies must be stopped in order to save Turtle Island's animals and indigenous people [LS4]. This could be the reason why the oil business reacted with such disproportionate outrage.[49]

When Rivers Were Trails
Having developed Thunderbird Strike, LaPensée moved to work on Where the Water Tastes Like Wine, [50] in cooperation with Johnnemann Nordhagen. Nordhagen's game allowed for wandering across the United States during the Great Depression, and the player's objective was to collect mostly bleak stories about the living conditions in the country. Although Where the Water Tastes Like Wine was a commercial failure,[51] it helped LaPensée reconsider its idea for educational purposes.

When Rivers Were Trails, a project directed by LaPensée and Nicholas Emmons, was advertised as "a $2 \mathrm{D}$ adventure game in which Oregon Trail meets Where the Water Tastes Like Wine." [52] The first of the aforementioned titles has been regarded as the most successful educational video game in history.[53] However, The Oregon Trail has faced serious accusations of privileging the white males' lifestyle, despite many female characters being present; [54] of suppressing the themes of slavery, ubiquitous in the 1840 os when the action ensues; [55]
[47] Minnesota Senate Republicans, op.cit.

[48] Government of Canada, The Daily - Oil and Gas Extraction, 2017, "StatCan" 2018, September 24, <https://www150.statcan.gc.ca/n1/daily-quotidien/180924/dq180924d-eng.htm>, accessed: 2.01.2021. [49] CBC Radio, op.cit.

[50] Dim Bulb Games, Where the Water Tastes Like Wine, Windows, Good Shepherd Entertainment, 2018.

[51] S. Vazquez, Where the water tastes like wine sells far below expectations, According To Creator, "Game Informer" 2018, March 31, <https://www.gameinformer.com/b/news/archive/2018/o3/31/where-the-watertastes-like-wine-sells-far-below-expectations-according-to-creator.aspx>, accessed: 1.01.2021.

[52] indianlandtenure, When Rivers Were Trails by Indianlandtenure, "itch.io" 2020, <https://indianland- tenure.itch.io/when-rivers-were-trails>, accessed: 1.01.2021.

[53] M. Jancer, How you wound up playing The Oregon Trail in computer class, "Smithsonian Magazine" 2016, July 22, <https://www.smithsonianmag.com/ innovation/how-you-wound-playing-em-oregontrailem-computer-class-180959851/>, accessed: 1.01.2021.

[54] B. Bigelow, On the road to cultural bias: A critique of The Oregon Trail CD-ROM, "Language Arts" 1997, vol. 74, no. 2, pp. 85 .

[55] B. Lokting, The long journey to reveal the Oregon Trail's Racist History, "Narratively" 2017, October 11, $<$ https://narratively.com/long-journey-reveal-oregon-trails-racist-history/>, accessed: 1.01.2021. 
and finally, of perpetuating "a racist narrative that privileges the ethos of white settlement through its refusal to engage directly with the genocidal consequences of westward expansion" [56] Therefore, to paraphrase Spike Lee, one can recognize the white settlement in the American West rather as a Holocaust than a Western, as opposed to The Oregon Trail's rhetoric. LaPensée herself, along with Emmons, stated that games like The Oregon Trail "reinforce colonial perspectives and false narratives regarding Indigenous peoples through visual representations, design, and the actions the player takes in order to win by reaching the West." [57]

When Rivers Were Trails, designed for Windows and iOS using Unity $\left[\mathrm{M}_{1}, \mathrm{M}_{2}, \mathrm{M}_{3}\right]$, constitutes an attempt to re-write the problematic narrative of The Oregon Trail [M5]. Although, just like the case of the former game, the player has to journey from the American East to the West [L1], the context becomes different. The main character is not a white settler but an Anishinaabe exiled from Fond du Lac after the enactment of the Nelson Act in 1889 [LN1]. His/her final destination is California [L1], but before reaching it, the player character has to wander from the U.S.-Canadian border through the Mid-West, which is an occasion to meet Native Americans of various tribes affected by the General Allotment Act. This act gave federal agents the power to subdivide Native American reservation lands and displace their population [LS3], which contributed to the violent history of U.S. genocidal politics towards indigenous people.

When Rivers Were Trails consists of two types of screens. The first one shows top-down board-like fragmented maps of the United States where the player moves their character [L1], choosing from several possible directions, if possible [ $\left.\mathrm{M}_{4}\right]$. At the beginning, the player has a fair amount of "well-being", medicines and food, the latter decreasing each time the player meets subsequent indigenous people or during random events $\left[\mathrm{L}_{1}, \mathrm{~L}_{5}\right]$. If any of these factors reaches zero, the player character dies [L4]. However, if the player reaches the end of the map with some surplus left, progress is made, and the game loads another fragment of the United States [L3]. Meanwhile, the game also shows a couple of boards stylized like silent film subtitles, which gradually inform the player about the fate of Native Americans in this country $\left[\mathrm{LS}_{2}, \mathrm{LS}_{5}\right]$. The second type of screens constitute illustrated conversations with particular indigenous people scattered around the United States, seen from a first-person perspective [LS1]. Here, When Rivers Were Trails offers illusory agency, allowing the player to make decisions affecting both the relationships with other Native Americans and particular types of surplus [L7]. The player can trade with indigenous people (e.g. exchanging medicine for food, or vice versa), hunt

[56] K. Slater, Who gets to die of dysentery?: Ideology, geography, and The Oregon Trail, "Children's Literature Association Quarterly" 2017, vol. 42, no. 4, pp. 374-395, DOI: 10.1353/chq.2017.0040.
[57] E. LaPensée, N. Emmons, Indigenizing Education with the Game..., p. 76. 
with them, or simply choose conversation with them and help them decide how they should behave towards federal agents. Depending on the chosen counsel, When Rivers Were Trails awards or punishes the player (by giving or taking some surplus), but also unlocks trivia about actual U.S. policy against Native Americans [L6]. These trivia moments were written by numerous Indigenous contributors representing multiple tribes, whose help became necessary for the game's credibility as an educational tool.[58]

However, the most important element of When Rivers Were Trails is a radical change in the portrayal of indigenous people. Unlike in The Oregon Trail, the dominant non-playable characters the player talks to are Native Americans and African-Americans. Although the in-game indigenous people belong to many tribes, their attitude to the player is peaceful [LN1]. For example, one of the Creek people, Wasu Maza, says: "You were our great enemies once, but none of that matters now." [59] None of that matters because the in-game Native Americans have a common enemy: the European white settlers. The situation of African-Americans even after the abolition is not good, either. Wandering over the West of the United States, the player can meet a black porter at the train station and learn about his almost servile working conditions. The porter has no name (everyone names him George, after the white industrialist George Pullnam) and is treated like a servant, as the in-game narrator explains [LN1]: "He takes care of the passengers, serving all of their needs and [...] gets to sleep about three hours in a car separate from the white passengers." [60]

When Rivers Were Trails also re-writes history in terms of gender. A young person named Memengwaa, who falls in love with the white representative's daughter, is said to be a Two-Spirit, meaning balancing both masculine and feminine aspects. An Apsaalooke person named Enemy-Hunter tells the player that "I was born a male but have the soul of a man and the soul of a woman." [61] In both examples, these in-game persons are not stigmatized within their communities, as Two-Spirits in many Native American societies were traditionally treated as endowed individuals who performed as spirituals, teachers, or traders. [62] Therefore, the inclusion of non-heteronormative characters - and people of color- in When Rivers Were Trails cannot be easily attributed to so-called "political correctness". By introducing such characters to the game, LaPensée and her co-workers brought justice to the groups never recognized in The Oregon Trail and many other games

[58] Ibidem, p. 79.

[59] Eadem, When Rivers Were Trails...

[60] Ibidem.

[61] Ibidem.

[62] L.B. Brown (ed.), Two Spirit People: American Indian, Lesbian Women and Gay Men, New York 1997;

S.-E. Jacobs, W. Thomas, S. Lang, eds., Two-Spirit

People: Native American Gender Identity, Sexual- ity, and Spirituality, Chicago 1997; M. Sheppard, J.B. Mayo, New social learning from two spirit native Americans, "The Journal of Social Studies Research" 2012, vol. 36, no. 3, pp. 263-282; M. Sheppard, J.B. Mayo, The Social Construction of Gender and Sexuality: Learning from Two Spirit Traditions, "The Social Studies” 2013, vol. 104, no. 6, pp. 259-270, DOI: 10.1080/o0377996.2013.788472. 
dedicated to the conquest of the West [LS 3 ]. Despite using mechanics similar to The Oregon Trail (for example, arcade sequences of hunting deer, fish, or buffalos), When Rivers Were Trails deconstructs dominant European-white-male narratives about indigenous people, hardened for years both in video games and other works of popular culture [LS4].

At the same time, When Rivers Were Trails emphasizes the communitarian behavior of Native Americans, who had never exploited fauna and flora on such a scale as the European settlers. A Salish Elder encountered near at the Lower Flathead River says meaningful words related to the game's title: "Not so long ago, rivers were homes and paths for us to visit with one another." [63] These were the rivers which connected the people before the European settlers built artificial paths, such as railroads.

As we have seen, the selected games co-made by Elisabeth LaPensée examine the issues of colonialism, racism and aggressive capitalism. At the same time, they "re-write" the conventional design of some video games. While The Oregon Trail repeated harmful stereotypes of "peaceful" settlement in the North America, When Rivers Were Trails leans towards deconstructing them and giving a voice to underprivileged indigenous people who experienced the genocidal practices of the U.S. government. While many side-scrolling video games rely on destruction, Thunderbird Strike allows also for reviving the dead victims of capitalist ventures, both in Canada and in the United States. Finally, while Space Invaders provided an ambiguous xenophobic fantasy about the invasion of the Other which conformed both to Japanese and the U.S. xenophobia, LaPensée's Invaders shows that it is the Other who defends themself against imperialist invasion, which, in this case, is European-American aggression.

One can also note the striking similarity between LaPensée's works and the early games by Muriel Tramis. The latter's games, such as Méwilo[64] and Freedom, [65] also promulgated local histories about the past of Martinique, this time from the perspectives of African-Caribbeans, whose ancestors were persecuted and exploited slaves dependent on the will of the French settlers. Both LaPensée and Tramis, even though their works are distant in time, represent the post-colonial turn in video games, considered the "contestation of colonial domination and the legacies of colonialism." [66] While Tramis' oeuvre was only recently recognized in 2018, when she received the Order of the Legion of Honour, LaPensée's career within the field of video games seems easier to identify. Nevertheless, both game designers managed to deconstruct the typical European narrative about civilizing the world and educating "savages", paving the way for other creators of indigenous descent.

[63] E. LaPensée, When Rivers Were Trails...

[64] M. Tramis, P. Chamoiseau, Méwilo, Atari ST, Coktel Vision, 1987.

\section{Conclusion}

[65] Idem, Freedom, Amiga, Coktel Vision, 1988. [66] A. Loomba, Colonialism, Postcolonialism, London 1998, p. 12. 
Aarseth E., Playing research: methodological approaches to game analysis, [in:] Game Approaches/Spil-Veje. Papers from Spilforskning.Dk Conference, ed. B.K. Walther, Aalborg 2004, pp. 28-29, <http://www.bendevane.com/VTA2012/herrstubbz/ wp-content/uploads/2012/01/02.GameApproaches2.pdf >, accessed: 2.01.2021

Barthes R., The death of the author, [in:] R. Barthes, Image, Music, Text, trans. S. Heath, London 1977, pp. 3-8.

Bazile J., L'Histoire à traverser. Regards vidéoludiques sur l'histoire de la Martinique dans Mewilo et Freedom de Muriel Tramis, [in:] Chemins de Traverse en fiction. Colloque interdisciplinaire de jeunes chercheureuses, École normale supérieure (ENS), Paris 2017, pp. 177-190

Bigelow B., On the road to cultural bias: A critique of The Oregon Trail CD-ROM, "Language Arts" 1997, vol. 74, no. 2, pp. 84-93

Bogost I., Persuasive Games: The expressive power of video games, Cambridge 2007

Bordwell D., Making Meaning: Inference and rhetoric in the interpretation of cinema, Cambridge - London 1989

Brown L.B. (ed.), Two Spirit People: American Indian, lesbian women and gay men, New York 1997

Brydon D., Re-writing The Tempest, "World Literature Written in English" 1984, vol. 23, no. 1, pp. 75-88, DOI: 10.1080/17449858408588811

CBC Radio, Thunderbird Strike: Controversial video game takes aim at oil industry, "CBC" 2017, November 3, <https://www.cbc.ca/radio/unreserved/from-video-games-to-ya-novels-how-indigenous-art-is-evolving-1.4384041/thunderbird-strike-controversial-video-game-takes-aim-at-oil-industry-1.4384559>, accessed: 1.01 .2021

CCS Working Group 2020, Week 2: Indigenous Programming (by J. Corbett, O. Laiti, J.E. Lewis, D. Temkin, available (upon login) at: $<$ http://wg20.criticalcodestudies.com/index.php? $\mathrm{p}=/$ discussion/70/week-2-indigenous-programming-main-thread\#latest>, accessed: 28.12.2020

Chang A.Y., Une Vie Bien Jouée/A Life Well Played: The cultural legacy of game designer Muriel Tramis, "Feminist Media Histories" 2020, no. 1, pp. 147-162. DOI: $10.1525 / \mathrm{fmh} .2020 .6 .1 .147$

Consalvo M., Console video games and global corporations, "New Media \& Society" 2006, no. 1, pp. 117-133, DOI: 10.1177/1461444806059921

Dim Bulb Games, Where the Water Tastes Like Wine, Windows, Good Shepherd Entertainment, 2018

Dunbar-Ortiz R., An Indigenous Peoples' History of the United States, Boston 2014

Dyer-Witheford N., De Peuter G., Games of Empire: Global capitalism and video games, Minneapolis 2009

Elias B. et al., Trauma and Suicide Behaviour Histories among a Canadian Indigenous Population: An empirical exploration of the potential role of Canada's residential school system, "Social Science \& Medicine" 2012, vol. 74, no. 10, pp. 1560-1569, DOI: 10.1016/j.socscimed.2012.01.026

Ensslin A., Literary Gaming, Cambridge - London 2014

Eskelinen M., The gaming situation, "Game Studies" 2001, vol. 1, no. 1, <http:// www.gamestudies.org/0101/eskelinen/>, accessed: 1.01.2021

Fellows M., Razack S., "The race to innocence: confronting hierarchical relations among women", "Journal of Gender, Race \& Justice", 1998, vol. 1, pp. 335-352, $<$ https://scholarship.law.umn.edu/faculty_articles/274>, accessed: 3.01.2021

Fernández-Vara C., Introduction to Game Analysis, New York - London 2015

Foucault M., Authorship: what is an author?†, "Screen" 1979, vol. 20, no. 1, pp. 13-34, DOI: 10.1093/screen/20.1.13

Government of Canada, The Daily - Oil and Gas Extraction, 2017, "StatCan" 2018, September 24, <https://www150.statcan.gc.ca/n1/daily-quotidien/180924/ dq180924d-eng.htm>, accessed: 2.01.2021 
Grace L., Space Invaders at 40: What the game says about the 1970s - and today, “The Independent" 2018, June 21, <https://www.independent.co.uk/life-style/ gadgets-and-tech/space-invaders-game-1970s-a8405886.html>, accessed: 1.01 .2021

indianlandtenure, When Rivers Were Trails by Indianlandtenure, itch.io, accessed: March 8, 2020, <https://indianlandtenure.itch.io/when-rivers-were-trails>, accessed: 1.01 .2021

Jacobs S.-E., Thomas W., Lang S. (eds.), Two-Spirit People: Native American Gender Identity, Sexuality, and Spirituality, Chicago 1997

Jancer M., How you wound up playing The Oregon Trail in computer class, "Smithsonian Magazine" 2016, July 22, <https://www.smithsonianmag.com/innovation/ how-you-wound-playing-em-oregon-trailem-computer-class-180959851/>, accessed: 1.01 .2021

Jankowski F. "Méwilo” i „Freedom” Muriel Tramis jako pierwsze gry postkolonialne” [in:] Ksenologie, eds. K. Olkusz, K.M. Maj, Kraków 2018, pp. 473-485

Jenkins H., Game design as narrative, "Computer" 2004, vol. 44, no. 53, pp. 118-130

Juul J., Games telling stories? A brief note on games and narratives, "Game Studies" 2001, vol. 1, no. 1, <http://www.gamestudies.org/0101/juul-gts/>, accessed: 1.01.2021

Kijewska-Trembecka M., Québec i Québécois: ideologie dążeń niepodległościowych, Kraków 2007

Konzack L., Computer game criticism: A method for computer game analysis, [in:] Video Games and Gaming Culture, ed. M.J.P. Wolf, New York - London 2016

LaPensée E., Invaders, Linux, Survivance, 2015

LaPensée E., Survivance: An Indigenous Social Impact Game, Burnaby 2014, <http:// web.archive.org/web/20200308205719/https://summit.sfu.ca/item/13984>, accessed: 3.01 .2021

LaPensée E., Thunderbird strike, [in:] Learning, Education \& Games, vol. 3: 100 Games to Use in the Classroom \& Beyond, ed. K. Schrier, Pittsburgh 2019, pp. $447-453$

LaPensée E., When Rivers Were Trails, Linux, Indian Land Tenure Foundation, Michigan State University's GEL Lab, 2019

LaPensée E., Emmons N., Indigenizing education with the game When Rivers Were Trails, "Amerikastudien" 2019, vol. 64, no. 1, pp. 75-93, DOI: 10.33675/ AMST/2019/1/8

LaPensée E., Lewis J.E., Call it a vision quest: Machinima in a first nations context, [in:] Understanding Machinima: Essays on Filmmaking in Virtual Worlds, ed. J. Ng, New York - London 2013, pp. 187-206

Laiti O., Ethnoprogramming: An Indigenous Approach to Computer Programming: A Case Study in Ohcejohka Area Comprehensive Schools, unpublished Master thesis, University of Lapland, 2016, <https://lauda.ulapland.fi/handle/10024/62624>, accessed: 2.01.2021

Laplantine F., Nouss A., Le métissage: un exposé pour comprendre, un essai pour réfléchir, Paris 1997, <http://classes.bnf.fr/actes/8/laplantine.pdf>, accessed: 2.01.2021

Lewis J.E., Arista N., Pechawis A., Kite S., Making Kin with the machines, "Journal of Design and Science" 2018, July 16, DOI: 10.21428/bfafd97b

Lokting B., The long journey to reveal the Oregon trail's racist history, "Narratively" 2017, October 11, <https://narratively.com/long-journey-reveal-oregon-trails-racist-history/>, accessed: 1.01.2021

Loomba A., Colonialism, Postcolonialism, London 1998

Majkowski T., Języki gropowieści. Studia o różnojęzyczności gier cyfrowych, Kraków 2019

Marino M.C., Critical Code Studies: Initial Methods, Cambridge 2020 
Mawhinney J.L., Giving Up the Ghost: Disrupting the (Re)Production of White Privilege in Anti-Racist Pedagogy and Organizational Change, unpublished Master thesis, University of Toronto, Toronto 1998, <https://tspace.library.utoronto. ca/handle/1807/12096>, accessed: 3.01.2021

Miller J.R., Skyscrapers Hide the Heavens: A history of Indian-White relations in Canada, Toronto - Buffalo 2000

Milloy J.S., McCallum M.J., A National Crime: The Canadian government and the residential school system, Winnipeg 2017

Minnesota Senate Republicans, Sen. David Osmek: MN Taxpayers should not be funding angry birds for eco-terrorists, "Minnesota Senate Republicans" (blog), 2017, October 26, <https://www.mnsenaterepublicans.com/sen-david-osmek-mn-taxpayers-not-funding-angry-birds-eco-terrorists/>, accessed: 1.01.2021

Mukherjee S., Video Games and Storytelling: Reading games and playing books, London 2015

Mukherjee S., Videogames and Postcolonialism. New York 2017

Nishikado T., Space Invaders, Arcade, Taito, 1978

Powell Ch. Peristerakis J., Genocide in Canada: A relational view, [in:] Colonial Genocide in Indigenous North America, eds. A.J. Woolford, J. Benvenuto, A.L. Hinton, Durham 2014, pp. 70-92

Rawitsch D., Heinemann B., Dillenberger P., The Oregon Trail, Multiple platforms, MECC, 1971

Ridon J.-X., Littérature-Monde, or redefining exotic literature?, [in:] Transnational French Studies: Postcolonialism and Littérature-Monde, eds. A.G. Hargreaves, C. Forsdick, D. Murphy, Liverpool 2010, pp. 195-208

Sheppard M., Mayo J.B., New social learning from two spirit native Americans, "The Journal of Social Studies Research" 2012, vol. 36, no. 3, pp. 263-282

Sheppard M.,, Mayo J.B., The social construction of gender and sexuality: learning from two spirit traditions, "The Social Studies" 2013, vol. 104, no. 6, pp. 259-270, DOI: $10.1080 / 00377996.2013 .788472$

Sicart M., Against procedurality, "Game Studies" 2011, vol. 11, no. 3, <http://gamestudies.org/1103/articles/sicart>, accessed: 1.01.2021

Slater K., Who gets to die of dysentery?: Ideology, geography, and The Oregon Trail, Children's "Literature Association Quarterly" 2017, vol. 42, no. 4, pp. 374-395, DOI: $10.1353 /$ chq.2017.0040

Stannard D.E., American Holocaust: The conquest of the new world, New York 1993

Staszenko, D., "Lollipop Chainsaw Goichiego Sudy i problem autorstwa w medium gier wideo," Homo Ludens, 2015, vol. 7, no. 2, pp. 153-162

Strużyna A., Artystyczne gry Anny Anthropy, "Homo Ludens" 2014, vol. 6, no. 1, pp. 187-198

Šisler V., Digital Arabs: representation in video games, "European Journal of Cultural Studies" 2008, vol. 11, no. 2, pp. 203-220, DOI: 10.1177/1367549407088333

Toumson R., Mythologie du métissage, [in:] Francophonie et identités culturelles, ed. C. Albert, Paris 1999, pp. 241-246

Tramis M., Chamoiseau P., Freedom, Amiga, Coktel Vision, 1988

Tramis M., Chamoiseau P., Méwilo, Atari ST, Coktel Vision, 1987

Trudel M., The Beginnings of New France, 1524-1663, Toronto 1973

Tuck E., Wayne Yang K., Decolonization is not a metaphor, "Decolonization: Indigeneity, Education \& Society" 2012, vol. 1, <https://jps.library.utoronto.ca/ index.php/des/article/view/18630>, accessed: 3.01.2021

Vazquez S., Where the water tastes like wine sells far below expectations, according to creator, "Game Informer" 2018, March 31, <https://www.gameinformer. com/b/news/archive/2018/03/31/where-the-water-tastes-like-wine-sells-far-below-expectations-according-to-creator.aspx $>$, accessed: 1.01.2021 
Vullierme J.-L., Miroir de l'Occident: Le nazisme et la civilisation occidentale, Paris 2014

Wolfe P., Settler colonialism and the elimination of the native, "Journal of Genocide Research" 2006, vol. 8, no. 4, pp. 387-409, DOI: 10.1080/14623520601056240

Zimmerman E., "Eric Zimmerman's Response." Electronic Book Review (blog), August 1, 2004, <https://electronicbookreview.com/essay/eric-zimmermans-response/>, accessed: 1.01.2021 